\title{
Popüler Bilim Kitapları Etkili Bir Öğretim Aracı Olarak Kullanılabilir Mi?1
}

Barış Eroğlu²

Halil İbrahim Sağlam³

Type/Tür:

Research/Araştırma

Received/Geliş Tarihi:

October 19/19 Ekim 2019

Accepted/Kabul Tarihi: June

22/ 22 Haziran 2020

Page numbers/Sayfa No:

656-678

Corresponding

Author/İletişimden Sorumlu

Yazar: bariserogl@gmail.com

\section{$\checkmark$ iThenticate}

This paper was checked for plagiarism using iThenticate during the preview process and before publication. / $\mathrm{Bu}$ çalışma ön inceleme sürecinde ve yayımlanmadan önce iThenticate yazılımı ile taranmıştır.

Copyright $\odot 2017$ by Cumhuriyet University, Faculty of Education. All rights reserved.

\section{Öz}

Araştırmanın amacı, Türkiye Bilimsel ve Teknolojik Araştırma Kurumu (TÜBİTAK) tarafından basımı gerçekleştirilen dört popüler bilim kitabının (Milyarlarca ve Milyarlarca, Olağanüstü Buluşlar, İki Kültür ve Meteor Avcısı) belirlenen bilimin doğası unsurları (Bilimsel bilginin deneysel doğası, Bilimsel bilginin sosyal ve kültürel yapı ile olan ilişkisi, Bilimsel bilginin değişebilir doğası ve Bilimsel bilgide yaratıcılık) açısından incelenmesidir. $\mathrm{Bu}$ inceleme sonunda ise bu kitapların bilimin doğası unsurları açısından etkili bir öğretim aracı olarak kullanılabilirlikleri değerlendirilmiştir. Araştırmada nitel paradigma hâkim olup yöntem olarak doküman incelemesinden yararlanılmıştır. Bu kapsamda araştırmaya dahil olan dört kitabın bilimin doğasına yönelik belirlenen dört temaya yönelik (bilimsel bilginin değişebilir doğası, bilimsel bilginin deneysel doğası, bilimsel bilginin sosyal ve kültürel yapı ile olan ilişkisi ve bilimsel bilgide yaratıcılık) içerik analizleri araştırmacılar tarafından gerçekleştirilmiştir. Araştırmacılar tarafından bağımsız bir şekilde Milyarlarca ve Milyarlarca isimli kitap analiz edilerek Cohen's Kappa değerleri hesaplanarak ortak görüşe varılmıştır. Ardından bir araştırmacı tarafından diğer analizlere devam edilmiştir. Elde edilen bulgular neticesinde Milyarlarca ve Milyarlarca ile özellikle Olağanüstü Buluşlar isimli kitap, belirtilen bilimin doğasına yönelik unsurlar açısından zengin bir içerik sunarken, İki Kültür ve Meteor Avı isimli kitapların bu açıdan oldukça az bir içeriğe sahip oldukları tespit edilmiştir. Popüler bilim kaynaklarının gerek içerdiği konular ve bu içeriğin eğitimdeki yeri ve önemi, gerek temin edilebilirliği, gerek ise yazım tarzı ve kullanılabilirliği tartışılmıştır.

Anahtar Kelimeler: Popüler bilim, bilimin doğası, içerik analizi, doküman incelemesi, öğretim aracı

\section{Suggested APA Citation/Önerilen APA Atıf Biçimi:}

Eroğlu, B., \& Sağlam, H. İ. (2020). Popüler bilim kitapları etkili bir öğretim aracı olarak kullanılabilir mi?. Cumhuriyet International Journal of Education, 9(3), 656-678.

http://dx.doi.org/10.30703/cije.634928

\footnotetext{
${ }^{1}$ Bu çalışma Aksaray Üniversitesi Bilimsel Araştırma Projeleri Koordinasyon Birimi tarafından desteklenmiştir. Proje numarası: 2017-051

${ }^{2}$ Dr. Öğr. Üyesi, Aksaray Üniversitesi, Eğitim Fakültesi, Temel Eğitim Bölümü, Sınıf Öğretmenliği Anabilim Dalı, Aksaray/ Türkiye

Assist. Prof. Dr., Aksaray University, Faculty of Education, Department of Primary Education, Aksaray/ Turkey e-mail: bariserog1@gmail.com ORCID ID: orcid.org/0000-0002-0643-5377
}

\footnotetext{
${ }^{3}$ Bilim Uzmanı, Aksaray Üniversitesi, Rektörlük İdari Personel, Aksaray/ Türkiye M.S., Aksaray University, Administrative staff of the Rectorate, Aksaray/ Turkey e-mail: hisaglam80@gmail.com ORCID ID: orcid.org/0000-0002-5299-6730
} 


\title{
Can Popular Science Books Be Used as an Effective Teaching Tool?
}

\begin{abstract}
The purpose of this research is to investigate the four popular science books (Billions and Billions, Remarkable Discoveries!, The Two Cultures, and The Chase of the Golden Meteor) pressed by The Scientific and Technological Research Council of Turkey (TUBITAK) in terms of the determined nature of science (NOS) aspects (Experimental nature of the scientific knowledge, Cultural and social embeddedness in scientific knowledge, The tentativeness of scientific knowledge, and Creativity in scientific knowledge). At the end of the investigation, it was assessed whether these books can be used as an effective teaching tool in terms of the NOS or not. Qualitative paradigm dominated this research and document analysis was used as a method. In this context, researchers made a content analysis of these four books involved in this research according to determined four NOS aspects (tentativeness of scientific knowledge, empirical nature of scientific knowledge, the social and cultural embeddedness of scientific knowledge, and the creativity in scientific knowledge). The researchers analyzed independently the book Billions and Billions for interrater reliability, calculated Kappa scores, and consensus settled. After that one researcher continued the content analysis process for other books. According to research results, the books named Billions and Billions and especially Remarkable Discoveries presents a richer content for the determined NOS aspects than, Two Cultures and The Chase of the Golden Meteor. The topics covered by popular science resources and the place and importance of this content in education, its availability, its writing style and usability were discussed.
\end{abstract}

Keywords: Popular science, nature of science, content analysis, document analysis, teaching tool

\section{Giriş}

Toplumlar, bilimsel gelişmelerin yoğun olarak yaşandığı dönemlerini Rönesansları olarak değerlendirmiş ve bazı bilimsel konuları ön plana çıkarmıştır. İçinde bulunduğu dönem içerisinde Dünya'nın şekli, uzayın yapısı, nanoteknoloji ya da küresel ısınma gibi bilimsel konular ön plana çıkmış ve diğerlerine nazaran toplumun daha fazla ilgisini çekmiştir. İnsanların ilgisini sadece konunun içeriği değil aynı zamanda ilgili bilimsel konuların yaşamlarını nasıl etkileyeceği de çekmeye başlamıştır. Dönemi içerisinde öne çıkan ve toplum tarafından ilgi ile takip edilen bu konular popüler bilim olarak adlandırılmış ve geniş bir kitleye hitap etmeye başlamıştır. Bu oluşması olağan bir durumdur. Çünkü Whitley'in (1985) de belirttiği üzere bilimin var olduğu ortamda iki farklı güruhtan bahsetmek mümkündür. Birisi bilimin saha uzmanları ise diğeri de bu konuda uzman olmayan bireylerden oluşan halktır. Sahada olmayan bireylere ise yapılan çalışmaların aktarılması özellikle bilim-toplum arasındaki bağın oluşması ve gelişmesi açısından önem arz etmektedir. Popüler bilimi kısaca tanımlayacak olursak, Parkinson ve Adendorff'un da (2004) bahsettiği üzere popüler bilim ile kastedilen, bireylerin bilimsel bilgi seviyesinin ve okuryazarlığının gelişmesini hedef alan ve akademinin dışına taşabilen önemli bir öğretim alanıdır. Popüler bilim yayınları farklı konu başlıkları içerebilmektedir. Yaygın bir şekilde bu konu başlıklarını şu şekilde sıralayabiliriz;

- Bilim insanlarının biyografileri

- Bilimsel gelişmelerin ortaya çıkışları ve döneme ait ilgi çekici olaylar

- Bilimsel gelişmelerin günlük yaşamımızdaki yeri ve etkileri 
- Günümüz bilim ve teknolojik gelişmelerinden haberler

- Eğlenceli deneysel uygulamalar.

İçerikleri oldukça geniş bir spektruma sahip olan popüler bilim yayınları bizlere bu bilgileri farkl1 formatlarda sunabilmektedir. Kisaca;

- Video görseller (belgesel videoları, bilim kurgu filmleri, bilimsel yarışma programları, vb.)

- Popüler bilim kitapları (yayınevleri tarafından basılan yazılı materyaller)

- Popüler bilim dergileri (kurum/ kuruluşlar ya da yayınevleri tarafından basılan periyodik popüler bilim yayınları)

- Sınıf dışı informal öğrenme ortamları (bilim ve eğlence merkezleri) şeklinde bu formatları kısaca özetleyebiliriz. Araştırmada özellikle bilimin doğası açısından popüler bilim eserlerinin nasıl bir içeriğe sahip olduğu ve bu durumları ile bir ögrretim aracı olarak eğitim sürecinde yer alıp alamayacakları tartışma konusu olacaktır.

Araştırmanın bir diğer çalışma alanını oluşturan bilimin doğası ile kastedileni genel bir çerçevede yorumlamak istersek bilimin doğasını; bilimin epistemolojisi, bir bilgiye ulaşma yolu ya da bilimsel bilginin gelişiminin doğasında yer alan değer ve inançlar olarak tanımlamak mümkündür (Abd-El- Khalick, Bell ve Lederman, 1998; Lederman, 1992). Bilimin doğasına yönelik gerçekleştirilen eğitimin öğrencilerin birer sorumlu vatandaş olarak kazanmaları gereken bilimsel okuryazarlık becerisini sağlamasını gerektiği literatürde yer alan çalışmalarda (Abd-El-Khalick ve diğ., 1998; Holbrook ve Rannikmae, 2007) belirtilmektedir. Yakın geçmişte bilimin doğası yaklaşımının son derece önemli bir eğitim çıktısı olduğu dünya çapındaki fen eğitim reform dokümanlarında yer almaktadır (Lederman, 2007). Bilimin doğasının anlaşılması, fen okuryazarlığının önemli bir bileşeni olarak görülmektedir (National Science Teachers Association [NSTA], 1982).

Popüler bilim üzerine gerçekleştirilen literatür çalışmaları incelendiğinde oldukça geniş bir çalışma grubu spektrumuna sahip olduğunu söylemek mümkündür. Gerek toplumda yer alan bireyler, gerekse örgün eğitimde yer alan öğrenciler ile gerçekleştirilmiş çalışmalara rastlamak mümkündür. Literatürde bu yönde gerçekleştirilen çalışmaların sonuçları genel bir çerçevede değerlendirilecek olunursa bilimi popülerleştirme adına ortaya konulan girişimlerin, bireylerin ilgili bilimsel konuyu anlamalarında ya da o konuya yönelik bakış açılarında pozitif etkilerinin ortaya çıktığını söylemek mümkündür.

$\mathrm{Bu}$ konuda ulusal literatürde popüler bilim anahtar kavramı altında incelenen lisansüstü dört tez çalışması (Ağca, 2016; Akben, 1992; Kılıç, 2009; Yıldız, 2015) bulunmakta ve bunlardan Kılıç (2009) tarafından ortaya konulan tez çalışmasına erişim hakkı bulunmaktadır. Kılıç tarafından ortaya konulan çalışmanın amacı yine TÜBİTAK tarafından Türkçe' ye çevirisi gerçekleştirilip baskısı sağlanan bir popüler bilim kitabının çeviri özellikleri incelenmiştir. Kılıç (2009) da tıpkı bu çalışmada belirtildiği gibi ulusal literatürdeki popüler bilim çalışmalarına yönelik boşluğa işaret etmektedir.

Afonso ve Gilbert (2013) tarafından gerçekleştirilen araştırmada ise İngilizce ya da Portekizce yazılmış 191 popüler bilim kitabı araştırmaya dâhil edilmiştir. Bu kitaplara ilişkin ise yoğun bir bilimsel geçmişe sahip olmayan 17 öğretmen adayından yazılı değerlendirme yapmaları istenmiştir. Araştırma sonucunda ise öğretmen 
adaylarının yazılı dönütleri neticesinde popüler bilim yayınlarının halkın bilime bakış açılarında ciddi pozitif etkilere sahip olabildiğini belirtmişlerdir.

Popüler bilim yayınları daha çok kitleye ulaşmak ve onları etkileyebilmek için akademik yazım tarzının dışına çıkan farklı bir üslup kullanmaktadır. Bu yazım farklılığına ilişkin Pelger ve Nilsson (2016) tarafından gerçekleştirilen çalışmada ise 64 biyoloji öğrencisinden projelerini halkın anlayabileceği bir dilde yazmaları ve uygulanan ankette de bu tarz bir yazım biçiminin onlara ne gibi katkılar sağladığını belirtmeleri istenmiştir. Öğrenciler, bu tarz bir yazım biçiminin onların olaylara bakış açılarını değiştirmelerini sağladığını aynı zamanda projelerine farklı bir açıdan bakma fırsatı yaşadıklarını belirtmişlerdir. Öğrenciler, popüler bilim yazarlığı ile anlatmak istedikleri bilimsel konuları metinlere daha rahat entegre edebildiklerini ve öğrencilerin ankette verdikleri yanıtlar incelendiğinde ise gelen dönütler 1şı̆̆ında metinlerin bu şekilde daha da anlaşılabilir hale geldiğini belirtmişlerdir. Aynı zamanda öğrenciler, bu süreçte fen okuryazarlıklarının da pozitif etkilendiğini ifade etmişlerdir.

Literatür çalışmaları, popüler bilim yayınlarının öğrenme ve motivasyon üzerinde pozitif etkiler oluşturabileceğini öne süren çalışmalar barındırmaktadır. Örneğin, Guerra ve Payne (1981) tarafından gerçekleştirilen çalışmada ortaya konulmak istenen, gerek popüler bilim kitaplarının gerekse gazete ve dergilerin bilime karşı öğrencilerin ilgisini çekmede faydalı olabileceğidir. Yine bu açıdan kitapların fen eğitimde etkili olabileceğini ortaya koymak amacı ile Halkia ve Botouropoulou (2005) astronomi ile ilgili "L' Astronomie Popularie" isimli kitabı toplumla iletişim için kullanılan dil, halka yeni bilgileri sunmak için ortaya koyduğu benzetimler, yeni bilginin temellendiği uslamlamaların gelişimleri ve epistemik yaklaşımlar açısından incelemiş ve olumlu yorumlarda bulunmuşlardır. Velentzas ve Halkia (2007) tarafından gerçekleştirilen çalışmada ise modern fizik konuları olan görelilik ve kuantum mekaniği içerisinde yer alan düşünce deneylerinin fizik ders kitabı ve popüler bilim kitaplarındaki yerleri incelenmiş ve bu konu başlıklarında ortaya konulan popüler bilim kitaplarına yönelik okuyucunun dikkati çekilmeye çalışılmıştır.

Hem doğa bilimlerine olan ilgiyi artırmak hem de öğrencilerin bilimsel metin analiz kabiliyetlerini geliştirmek adına Simon, Steindl, Larcher, Kulac ve Hotter (2016) tarafından gerçekleştirilen çalışmadan da benzer olumlu sonuçlar elde edilmiştir. Üniversitede geliştirilen genç bilim haberciliği programı kapsamında lise öğrencileri ile pilot çalışma gerçekleştirilmiştir. Öğrenciler, araştırma sonucunda çalıştay şeklinde gerçekleştirilen bu uygulamadan oldukça memnun olduklarını ve bu tarz projelere daha çok katılmak istediklerini belirtmişlerdir. Araştırmanın sonunda ise doğa bilimlerine karşı duyulan ilgide bir artış saptanmıştır.

Literatürde popüler bilim yayınlarının özellikle bilimin doğası ve tarihi açısından incelendiği çalışmalara rastlamak da mümkündür. Çakmakçı (2017) tarafından gerçekleştirilen çalışmada belgesel niteliği taşıyan video görseller, fen bilgisi öğretmen adayları ile birlikte bilimin tarihi ve doğası dersinin işlenişi esnasında etkili bir araç olarak kullanılmıştır. Öğretmen adayları ile gerçekleştirilen 14 haftalık uygulama boyunca öğretmen adaylarından ders içeriğine uygun olacak şekilde video görsellerden sahneler yakalamaları ve bu sahnelere yönelik sınıf içi tartışmalar ve nihai bir rapor ortaya koymaları istenmiştir. Araştırma sonuçları ise geniş bir yelpazede sunulmuştur. Araştırmaya katılan öğretmen adaylarının büyük bir 
kısminda istatistiksel olarak bilimin doğası hakkındaki görüşlerinde, naif görüşlerden bilgiliye doğru bir yönelme olduğu gibi (ör. teori ve kanun arasındaki ilişki, gözlemlerin teori temelli doğası, bilimsel teorilerin doğası), öğretmen adaylarının görüşlerinde yine pozitif değişimlere ulaşılmış ancak bunların istatistiksel olarak bir anlam taşımadığ1 belirtilmiştir (ör. Bilimsel modeller ve gerçeklik, sınıflandırma şemaları ve gerçeklik). Araştırmadan elde edilen önemli sonuçlardan birisi de öğretmen adaylarının bilimsel teori ve kanun konusunda kafalarının karışık olduğu yönünde bulgulara rastlanılmasıdır. Çakmakçı (2017) gerçekleştirdiği çalışmada ek olarak popüler bilime yönelik medya araçlarının sınıflarda farklı şekillerde değerlendirilebileceğini ve fen okuryazarliğı anlamında etkili bir araç olarak kullanılabileceğini belirtmektedir.

Popüler bilim sadece kendine yayınlar şeklinde değil, uygulamalar olarak da yer bulmaktadır. Bu anlamda, Watermeyer (2013) gerçekleştirdiği çalışmada bilimin popüler zeminlere taşınmasında bilim şovlarının etkisinin oldukça fazla olduğunu belirtmektedir. Çalışmada özel bir şirket tarafından gerçekleştirilen bilim şovları ile STEM (Science-Technology-Engineering-Mathematics) yani bilim, teknoloji, mühendislik ve matematik anlayışının toplum nezdinde anlaşılabilmesi ve bu bilimsel altyapının topluma indirgenmesi hususunda önemli ve olumlu sonuçlar elde edilmiştir.

Benzer bir uygulama ise Price, Gean ve Barnes (2015) tarafından gerçekleştirilmiştir. Ülkemizde de geniş izleyici kitlesine sahip bir bilimsel şov programı olan Mythbusters (Efsane Avcıları) ekibi tarafından organize edilen ve Mythbusters: The Explosive Exhibition isimli yarışmalardan ve popüler bilimsel uygulamalarından oluşan geniş bir uygulama alanından yararlanılmıştır. Araştırmacılar bu alandaki uygulamalara yönelik 333 çocuğun uygulama öncesi ve sonrası testler yardımı ile onların bu uygulamalarda yer alan bilimsel konuları öğrenmelerine ve fene karşı tutumlarına yönelik etkisini incelemişlerdir. Araştırma sonucunda öğrencilerin hem bilimsel bilgilerinde eklentiler oluştuğu hem de fene bakış açılarında olumlu değişimler olduğu gözlemlenmiştir.

Majetic ve Pellegrino (2014) tarafından gerçekleştirilen çalışmada ise medyada yer alan bilimsel haberler incelenmiştir. Araştırmada lisans öğrencileri medya haberlerini belirli kriterler eşliğinde içerik analizine tabii tutmuşlardır. Çalışma ile bu tarz bir uygulamanın öğrencilerin okuma becerileri üzerinde olumlu etkilerinin olduğu ortaya çıkmıştır. Aynı zamanda, öğrencilere bir amatörün gözünden bir profesyonel bilimsel metin nasıl eleştirilir yetisinin de kazandırılması hedeflenmiş ve başarılı olunduğu belirtilmiştir.

Lin, $\mathrm{Wu}$, Cho ve Chen (2015) tarafından gerçekleştirilen çalışmada amaç, nanoteknoloji konusunda örgün eğitim ve popüler bilim arasında köprü kurmaktır. Bu bağlamda bilimsel konu olarak nanoteknoloji ele alınmıştır. Çalışma, dört ilkokulda gerçekleştirilmiş ve olumlu sonuçlar elde edilmiştir. Araştırmacılar ortaya koydukları program yardımı ile nanoteknoloji konusunun örgün eğitime popüler bilim aracılığı ile entegre edilebileceğini belirtmektedirler.

Çakmakçı ve Yalaki (2012) tarafından ortaya konulan çalışmanın amacı ise gazetelerde yer alan bilimsel haberlerin bilimin doğası açısından incelenerek bir eğitim materyali haline getirilmesidir. Çalışma iki yıl sürmüş ve amaç fen bilgisi öğretmenleri ve öğretmen adaylarının bilimin doğasına yönelik anlayışların iyileştirilmesidir. Araştırmadan elde edilen sonuçlar değerlendirildiğinde ise fen bilgisi öğretmenlerinin 
bilimin doğası unsurları ve medya haberleri arasında bağ kurmada zorlandıkları tespit edilmiştir. Araştırmacılar aynı zamanda dersi yürüten öğretmenin konu hakkında sahip olduğu alan bilgisinin bu süreci yönetmede oldukça elzem bir rolü olduğuna dikkat çekmiştir.

Singh (2011) tarafından ortaya konulan çalışmada ise amaç popüler bilim yayınları yardımı ile öğrencilerin fizik dersine karşı olan ön yargılarının önüne geçmektir. Araştırmacı, öğrencilerin fizik dersini oldukça sıkıcı ve durağan olarak değerlendirdiklerini ve popüler bilim yayınlarına ilgisiz olduklarını tespit etmiş ve bunun üzerine dersin işleyişinde farklılığa gitmiştir. Araştırmacı National Aeronautics and Space Administration (NASA)' ya ve benzer kuruluşlara ait internet sitelerinde yer alan bilimsel haberleri dersine entegre etmiştir. Çalışmada amaçlanan ise, öğrencilerin hem fizik dersine karşı ilgilerinin hem de özgüvenlerinin artmasını sağlamaktır. Araştırmadan elde edilen pozitif sonuçlardan göze çarpanları

- Öğrenciler fizik alanının halen gelişmekte olduğunu farketmeleri

- Daha fazla popüler bilim makalesine ilgi göstermeleri ve okumalarıdır.

TTKB tarafından ortaya konulan Fen Bilimleri Dersi Öğretim Programı 2018'e göre eğitim sistemimizin temel amacı şu şekilde tanımlanmıştır:

Eğitim sistemimizin temel amacl değerlerimiz ve yetkinliklerle bütünleşmiş bilgi, beceri ve davranışlara sahip bireyler yetiştirmektir (TTKB, 2018, s.5).

Ortaya konulan bu program kapsamında yukarıda belirtildiği üzere topluma ait değerleri benimsemiş, bu değerler ile birlikte yetkinliklerin de kazandırıldığı bireylerin yetiştirilmesi hedeflenmiştir. Çalışmamızda özellikle ilkokul sınıf öğretmenleri ve ortaokul fen bilimleri öğretmenlerimiz ve bu anabilim dallarında öğrenim gören lisans öğrencilerine odaklanılmıştır. Bunun sebebi, hem görev alacakları sınıflardaki öğrencileri açısından hem de kendi gelişimleri açısından fen bilimleri derslerinin, popüler bilim kaynakları ile ilişkilendirilebileceği öngörüsüdür.

TTKB (2018) tarafından ortaya konulan Fen Bilimleri Dersi Öğretim Programı 2018'nda yer alan Öğretim Programının Özel Amaçları incelendiğinde ise popüler bilim yayınlarında temel alınan konu ve konulara bakış açısı ile ciddi örtüşmeler tespit edilmiştir. Daha önce de belirtildiği gibi popüler bilim yayınları bilim insanlarının yaşamlarına, temel fen konularının daha sade basit bir dille anlatımına, günlük yaşamımızda yer alan problemlerin çözümüne yönelik eğlenceli uygulamalara vb. konu başlıklarına yer vermektedir. Öğretim programının özel amaçları incelendiğinde ise ciddi anlamda popüler bilim yayınlarının konu içerik ve yaklaşımları ile örtüştüğü tespit edilmiştir. Örneğin;

- Birey, çevre ve toplum arasındaki karşılıklı etkileşimi fark ettirmek; toplum, ekonomi ve doğal kaynaklara ilişkin sürdürülebilir kalkınma bilincini geliştirmek,

- Fen bilimleri ile ilgili kariyer bilinci ve girişimcilik becerilerini geliştirmek,

- Bilim insanlarınca bilimsel bilginin nasıl oluşturulduğunu, oluşturulan bu bilginin geçtiği süreçleri ve yeni araştırmalarda nasıl kullanıldığını anlamaya yardımcı olmak,

- Doğada ve yakın çevresinde meydana gelen olaylara ilişkin ilgi ve merak uyandırmak, tutum geliştirmek şeklindeki maddelerin programda yer aldığı gözlenmektedir (TTKB, 2018). 
Yukarıda belirtilen ifadeler aynı zamanda popüler bilim yayınlarının değindiği konular arasında yer almaktadır. Bilimin doğası, fen eğitimi ve popüler bilim alanı arasında bir köprü niteliği taşıyabilecek potansiyele sahip olduğu düşünülen popüler bilim yayınları bu sebep ile araştırmaya konu edinilmiştir. Araştırmanın temel amacı, popüler bilim yayınlarının bilimin doğası açısından fen öğretiminde etkili bir araç olarak kullanılıp kullanılamayacağıdır. Bu bakış açısı ile bu araştırmada hedeflenen, ele alınan kitapların belirlenen bilimin doğası unsurları açısından içeriklerinin incelenmesi ve ileriye dönük olarak gerçekleştirilecek deneysel ya da eylem araştırması gibi çalışmalara zemin hazırlanmasının sağlanmasıdır.

Popüler bilim kitaplarının içerik analizine tabii tutulması, onların içerisinde yer alan potansiyellerin de ortaya çıkarılarak bilimsel bir değer kazanmasını sağlayacağı ve bu anlamda özellikle bireylerde fen okuryazarlı̆̆ı kavramının daha net anlaşılması ve yaygınlaşmasına yardımcı olacağı düşünülmektedir.

\section{Yöntem}

Araştırmada yöntem olarak doküman incelemesi yönteminden yararlanılmıştır. Doküman incelemesi, araştırılması hedeflenen olgu veya olgular hakkında bilgi içeren yazılı materyallerin analizini kapsar (Yıldırım ve Şimşek, 2013).

Doküman incelemesinde şu aşamalar izlenmiştir (Forest, 1995) ( akt. Yıldırım ve Şimşek, 2013, s. 223).

1. Dokümanlara ulaşma

2. Orijinalliğini kontrol etme

3. Dokümanları anlama

4. Veriyi analiz etme

5. Analize konu olan veriden örneklem seçme

6. Kategorilerin geliştirilmesi

7. Analiz biriminin saptanmas1

8. Sayısallaştırma

\section{Dokümanlara Ulaşma}

Araştırmaya dâhil edilen kitaplar hâlihazırda TÜBİTAK tarafından basımı devam eden kitaplardır ve bu kitaplara erişim sağlanabilmektedir.

\section{Orijinalliğini Kontrol Etme}

Araştırmaya konu olan kitaplar çeşitli yayınevleri ve kitap satış noktalarından ücretlerinin karşılıkları ödenerek alınmış olup Kültür ve Turizm Bakanlığı'na ait bandrolleri bulunmaktadır. Bu bandrol kitapların orijinalliğinin kanıtı durumundadır.

\section{Dokümanları Anlama}

Araştırmaya konu olan kitaplar tekrar baştan sona her iki araştırmacı tarafından analitik bir biçimde okunmuş, detaylı bir şekilde incelenmiş ve notlar alınmıştır. Araştırma kapsamında belirlenen bilimin doğası unsurları ışığında kitaplar incelenmiş ve gerekli notlar alınmıştır. 


\section{Veriyi Analiz Etme}

Araştırma süresince sadece ismi belirtilen dört kitap veri kaynağı olarak kullanıldı̆̆ için detaylı bir veri analizi gerekmektedir. Bu aşamada veriler içerik analizine tabii tutulmuştur.

Analize konu olan veriden örneklem seçme. Araştırmada yer alan dört kitabın tamamı veri analiz sürecine dahil edilmiştir. Yani araştırmada yer alan veri evreni ve örneklemi aynı olup isimleri belirtilen dört kitaptır.

Kategorilerin geliştirilmesi. Araştırma süresince gerek kategorilerin oluşturulması, gerek ise kodlama sürecinde her iki araştırmacı tarafından kuramsal hassasiyet göz önünde bulundurulmuştur. Kuramsal hassasiyetlilik, nitel araştırmada araştırmacının verilerdeki en önemli unsurları tespit etmesi, bunu anlamlı bir şekilde fark etmesi ve buna anlam vermesi yeteneği olarak tanımlanır (Ekiz, 2009). Araştırmamız süresince fen eğitimi ve bilimin doğası'na yönelik ortaya konulan kuramlar, veri analiz sürecinde bizlere yol göstermiştir. Bu sebeple araştırma kapsamında McComas (2002) tarafından da belirtilen dört temel bilimin doğası unsuru araştırmada yer alan ders kitaplarının içerik analizi sürecinde kategorileri oluşturmuştur. Bunlar;

- Bilimsel bilginin deneysel doğası

- Bilimsel bilginin sosyal ve kültürel yapı ile olan ilişkisi

- Bilimsel bilginin değişebilir doğası

- Bilimsel bilgide yaratıcılik şeklindedir.

Ayrıca, belirlenen bu dört temel kategoriye yardımcı olabilecek bazı unsurlardan yararlanılmıştır. Bunlar; McCommas, Clough ve Almazroa (2002) tarafından incelenen sekiz fen eğitimi standardı dokümanı sonucu ortaya konulan mutabakata varılmış görüşler ile McCommas tarafından ortaya konulan “bilim mitleri” dir.

Analiz biriminin saptanması. Araştırma kapsamında planlanan, kitaplarda yer alan cümle ya da paragrafların analiz birimi olarak belirlenmesidir. Burada araştırmanın kodlanması aşamasında bir hususa dikkat edilmiştir. Araştırmada yer alan kodlar; kelime, cümle ya da paragraf olarak aranmanın ötesinde bir tema başlı̆̆1 altında incelenmiştir. Örneğin Milyarlarca ve Milyarlarca isimli kitapta ortaya konulan bir kod, bir paragraftan ibaret olabildiği gibi aynı zamanda birden çok sayfayı ya da paragrafı kapsayan bir boyutta olabilmiştir. Bunun sebebi, bizlerin araştırmamızda kodları bir tema doğrultusunda oluşturmamızdır. Yani, bilimsel bilgide yaratıcılık kategorisine işaret eden kod, birkaç sayfaya yayılmış bir konu içeriğinden de meydana gelebileceği gibi, bir paragraflık açıklamadan da ibaret olabilir. Ortaya konulan bu kodlara ilişkin örneklere, araştırmanın Analiz-Bulgular başlığı altında yer verilmiştir.

Veri analiz sürecinde araştırma kapsamında incelenen dört kitaptan Milyarlarca ve Milyarlarca her iki araştırmacı arasındaki kodlayıcı güvenirliğinin sağlanması ve nitel paradigmadan kaynaklanan subjektifliğin önüne geçmek adına her iki araştırmacının kodlarının karşılaştırılması için faydalanılmıştır. $\mathrm{Bu}$ süreç şu aşamalardan oluşmaktadir.

- İlk olarak birinci araştırmacı, belirlenen dört kategori kapsamında Milyarlarca ve Milyarlarca isimli kitabı açık kodlama süreci içerisinde 
kodlamıştır. Ortaya çıkarılan kodlar Nvivo 11 yazılımı yardımı ile kayıt altına alınmıştır.

- Ardından, bu kod listesi Nvivo yazılımı aracılığı ile ikinci araştırmacıya verilmiş ve ikinci araştırmacı da tıpkı birinci araştırmacı gibi Milyarlarca ve Milyarlarca isimli kitabı analiz etmiştir. Araştırmacı analizi süresince birinci araştırmacı tarafından literatür desteği ile oluşturulan kodlardan faydalanarak analizini tamamlamıştır.

- Daha sonra araştırmacılar yan yana gelerek ortaya çıkan Kappa İstatistik Katsayısı üzerine ortak bir kanıya varmak için yanyana gelerek analiz sürecini tartışmış ve "Milyarlarca ve Milyarlarca" isimli kitabın içerik analizine yönelik \%100 uyum sağlamıştır. Bu sebeple, Kappa İstatistik Katsayıları belirtilen kodların tamamı değil, mutabakata varılan kodlar ilgili kitapta belirtilmiştir.

- Ardından varılan mutabakat ile ikinci araştırmacı diğer üç kitabı, oluşturulan bu kodlar yardımı ile analiz etmiştir. Bu süreçte de yine her iki araştırmacı da yan yana gelerek kodlama sürecini değerlendirmişlerdir.

Araştırmada kodlayıcılar arası güvenirlik Cohen'in Kappa İstatistik Katsayısı ile tespit edilmiştir. Cohen'in Kappa Katsayısı iki değerlendirici arasındaki güvenirliği ölçen bir istatistiki yöntemdir. Bu değerleri ve uygulamayı bize Nvivo 11 sağlayabilmiştir. Araştırmada Landis ve Koch (1977) tarafından ortaya konulan Kappa istatistik değerlerinden yararlanılmıştır.

Araştırmada kodlayıcılar arasında elde edilen Kappa Katsayı değerleri, araştırmanın Analiz Bulgular başlığında verilmiştir.

Sayısallaştırma. Araştırma sonucunda elde edilen veriler (Kappa İstatistik Katsayısı, tema ve kodların yüzdeleri vb.) yüzde dağılımlarının araştırma sonunda sunulması sürecidir. Bu basamakta elde edilen veriler de yine araştırmanın AnalizBulgular basamağında belirtilmiştir.

\section{Evren ve Örneklem}

Araştırmada yer alan dokümanlar, TÜBİTAK tarafından Türkçe' ye uyarlanarak yeni basımlarına araştırmanın gerçekleştirildiği süreçte de ulaşılabilen şu kitaplardır;

\section{Bulgular}

Araştırmanın bu basamağında ilk olarak kodlayıcılar arasındaki güvenirliğin sağlanması için hesaplanan Kappa İstatistik Katsayısına ve ardından gerçekleştirilen içerik analizlerine ilişkin bulgulara yer verilmiştir.

\section{Kodlayıcılar Arası Güvenirliğe İlişkin Bulgular}

Yukarıda da belirtildiği üzere araştırmada kitaplara yönelik içerik analizlerinde tematik kodlamadan yararlanılmıştır. Birinci araştırmacı tarafından Milyarlarca ve Milyarlarca isimli kitaba yönelik açık kodlama yaklaşımı ile kodlar oluşturulmuştur. Ardından oluşturulan bu kodları kullanarak ikinci araştırmacı, bağımsız bir şekilde kitaplara yönelik içerik analizlerini gerçekleştirmiştir. Gerçekleştirilen bu iki tematik analiz sürecinin tamamlanmasının ardından her iki araştırmacı arasındaki kodlayıcı güvenirliği Kappa İstatistik Katsayısı yardımı ile hesaplanmıştır. Aşağıda yer alan Tablo 
1'de araştırmacılar tarafından gerçekleştirilen kodlamalar sonucu elde edilen kodlar ve Kappa Katsayı değerleri verilmiştir.

Tablo 1.

Kodlar ve Kappa Katsayı Değerleri

\begin{tabular}{ll}
\hline Bilimsel bilgide yaratıcılık & Kappa Değeri \\
\hline Kod İsmi & 0,4998 \\
\hline Analojiden faydalanma & 0,5759 \\
Bilgiler arası ilişki kurabilme & 0,4989 \\
Bilginin kullanım kolaylığı & 0,5 \\
Yeni bir bakış açısı & 0,6449 \\
Düşünce deneyleri gerçekleştirme & 04983 \\
Pratik buluşlar & \\
Bilimsel bilginin değişebilirliği & 0,5 \\
\hline İçinde bulunduğu dönemde geçerlilik & 0,5 \\
Tarihsel süreç içindeki değişimi & 0,7746 \\
Coğrafi yapını etkisi & 0,4996 \\
Farklı teorilerin varlığı & 0,5 \\
Popüler kavramsal değişim & 0,5 \\
Tarihi bakış açısı değişimi & 0,5 \\
Teolojik yaklaşıma yönelik bilimsel açıklama & 0,5 \\
Teorik bakış açısı farklılığı & 0,5 \\
Yeni bilgiye tepki & 0,5 \\
Yeni bilimsel bilgilere dayalı çıarımlar & \\
Bilimsel bilginin deneysel yapısı & 0,4977 \\
\hline Bilgiye dayalı deneysel uygulamalar & 0,4991 \\
Bilimsel yöntem & 0,5 \\
Deneylere coğrafyanın etkisi & 0,5531 \\
Olaylara açılık getirme & 0,5159 \\
Yeni bilimsel buluşlar sağlama & \\
Bilimsel bilginin sosyal ve kültürel yapı̀ ile ilişkisi & 0,4997 \\
\hline Bilimsel bilgiye yönelik çatı̧ma & 0,5 \\
Bilimsel bilgiye yönelik uzlaşı & 0,5924 \\
Bilimsel gelişmelerin toplum üzerindeki etkisi & 0,5 \\
Nüfus yapısının etkisi & 0,5 \\
Toplumun bilime pozitif yaklaşımı & 0,4984 \\
Toplumun çevre üzerindeki etkisi & 0,4982 \\
Yaşamı kolaylaştıran bilimsel gelişmeler & 0,5 \\
Yeni kavrama yönelik belirsizlik & \\
\hline
\end{tabular}

Tablo 1'de yer alan değerler incelendiğinde, kodlayıcılar arasında orta derece ve büyük çapta uyumun sağlandığı ortaya çıkmıştır. Bu aşamanın ardından araştırmacılar bir araya gelerek, kodlarını karşılaştırmış ve \%100 uyum sağlayana kadar kodlarını gözden geçirmişlerdir. Uyumun sağlanmasının ardından ikinci araştırmacı tarafından diğer kitapların analizlere devam edilmiştir.

\section{Kitaplardaki Bilimin Doğasına İlişkin Bulgular}

Milyarlarca ve Milyarlarca isimli kitaba ait bulgular. Araştırmamızda Milyarlarca ve Milyarlarca isimli kitaba dair elde edilen kodlar ve frekansları Şekil 1' de yer almaktadır. Burada yer alan kodlar, daha önce de belirtildiği üzere her iki araştırmacı tarafından gerçekleştirilen içerik analizi sonucunda görüş birliği ile belirlenen kodlardir. 


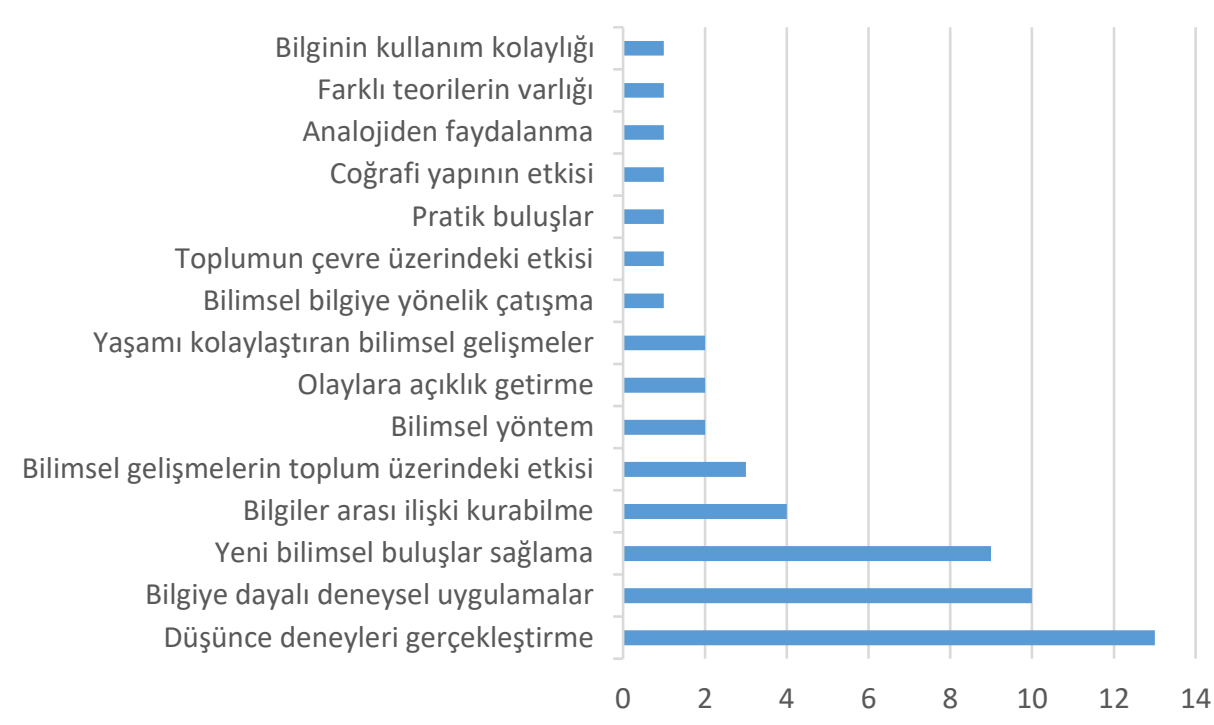

Şekil 1. Milyarlarca ve milyarlarca isimli kitaba ait kodlar

Araştırma bulgularına göre, Milyarlarca ve Milyarlarca isimli kitaba yönelik, belirlenen bilimin doğası unsurları açısından gerçekleştirilen içerik analizi sonucunda ortaya çıkan kodlar Tablo 2'de yer alan tabloda belirtilmiştir.

Tablo 2.

Milyarlarca ve Milyarlarca İsimli Kitaba Ait Kodlar ve Frekanslar

\begin{tabular}{cc}
\hline Kod İsmi & Frekans \\
\hline Düşünce deneyleri gerçekleştirme & 13 \\
Bilgiye dayalı deneysel uygulamalar & 10 \\
Yeni bilimsel buluşlar sağlama & 9 \\
Bilgiler arası ilişki kurabilme & 4 \\
Bilimsel gelişmelerin toplum üzerindeki etkisi & 3 \\
Bilimsel yöntem & 2 \\
Olaylara açılık getirme & 2 \\
Yaşamı kolaylaştıran bilimsel gelişmeler & 2 \\
Bilimsel bilgiye yönelik çatışma & 1 \\
Toplumun çevre üzerindeki etkisi & 1 \\
Pratik buluşlar & 1 \\
Coğrafi yapını etkisi & 1 \\
Analojiden faydalanma & 1 \\
Farklı teorilerin varlığı & 1 \\
Bilginin kullanım kolaylığı & 1 \\
Toplam Kod Sayısı & \\
\end{tabular}

Tablo 2 ve Şekil 1'de yer alan ve sıklıkla karşılaşılan kodlara ilişkin ilgili kitapta yer alan örnek kod, aşağıda sunulmuştur.

Kod İsmi: Düşünce Deneyi Gerçekleştirme

Sayfa: 20-21

...sırası gelmişken... 
Nükleer parçalanmayı ilk kez Macar göçmeni fizikçi Leo Szilard Eylül 1933'te Londra'da düşünmüştü. Atom çekirdeğinde gizli muazzam enerjinin insan müdahalesiyle açı̆̆a çıkarılıp çıkarılamayacă̆ın merak ediyordu. Atom çekirdeğine bir nötron firlatılması durumunda ne olacağı sorusuna cevap arıyordu. (Elektrik yükü taşımayan nötron, çekirdekteki protonlar tarafindan elektriksel olarak itilmeyecek ve nötron doğrudan çekirdekle çarpışacaktır). Southhampton Row'daki bir kavşakta trafik ışı̆̆ında beklerken, bir nötron tarafindan vurulduğunda iki nötron firlatan bir madde, bir kimyasal element olabileceği aklına geldi. Bu nötronlardan her biri de başka nötronlar firlatabilirdi. Böylece Szilard'ın zihninde, sayıları katlanarak artan nötronlar ve parçalanarak să̆a sola dağılan atomlarla bir zincirleme nükleer tepkime imgesi oluştu. O gece Strand Palace Oteli'ndeki küçük odasinda, eğer bir madde üzerinde kontrollü zincirleme nötron tepkimesi yaratılabilirse, o maddenin sadece birkaç kilogramından açı̆̆a çıkacak enerjiyle küçük bir kentin bir yıllık enerji ihtiyacının karşılanabileceğini ya da ĕ̆er enerji birden boşalırsa, o kentin yok olabileceğini hesaplad. Szilard daha sonra Amerika Birleşik Devletleri'ne göç etti ve kendine çarpandan daha fazla sayıda nötron firlatan bir kimyasal element olup olmadı̆̆ın bulmak için tüm elementler üzerinde sistematik bir araştırmaya girişti. Uranyum umut vaat eden bir aday gibi görünüyordu. Albert Einstein'ı Başkan Roosevelt'e, Amerika Birleşik Devletleri'ni atom bombası yapmaya teşvik ettiği o ünlü mektubu yazmaya ikna etti. Szilard 1942 yılında Chicago'da gerçekleştirilen ve atom bombasının yolunu açan ilk zincirleme uranyum tepkimesinde önemli rol oynad. Szilard ömrünün geri kalan bölümünüyse, yapımını ilk düşünen kişi olduğu bu silahın tehlikeleri hakkında uyarılarda bulunmakla geçirdi. O da başka bir yoldan, katlanarak büyümenin ürkütücü gücünü keşfetmişti. ..."

Olağanüstü buluşlar isimli kitaba ait bulgular. Araştırma bulgularına göre "Olağanüstü Buluşlar" isimli kitaba yönelik, belirlenen bilimin doğası unsurları açısından gerçekleştirilen içerik analizi sonucunda ortaya çıkan kodlar Şekil 2'de belirtilmiştir.

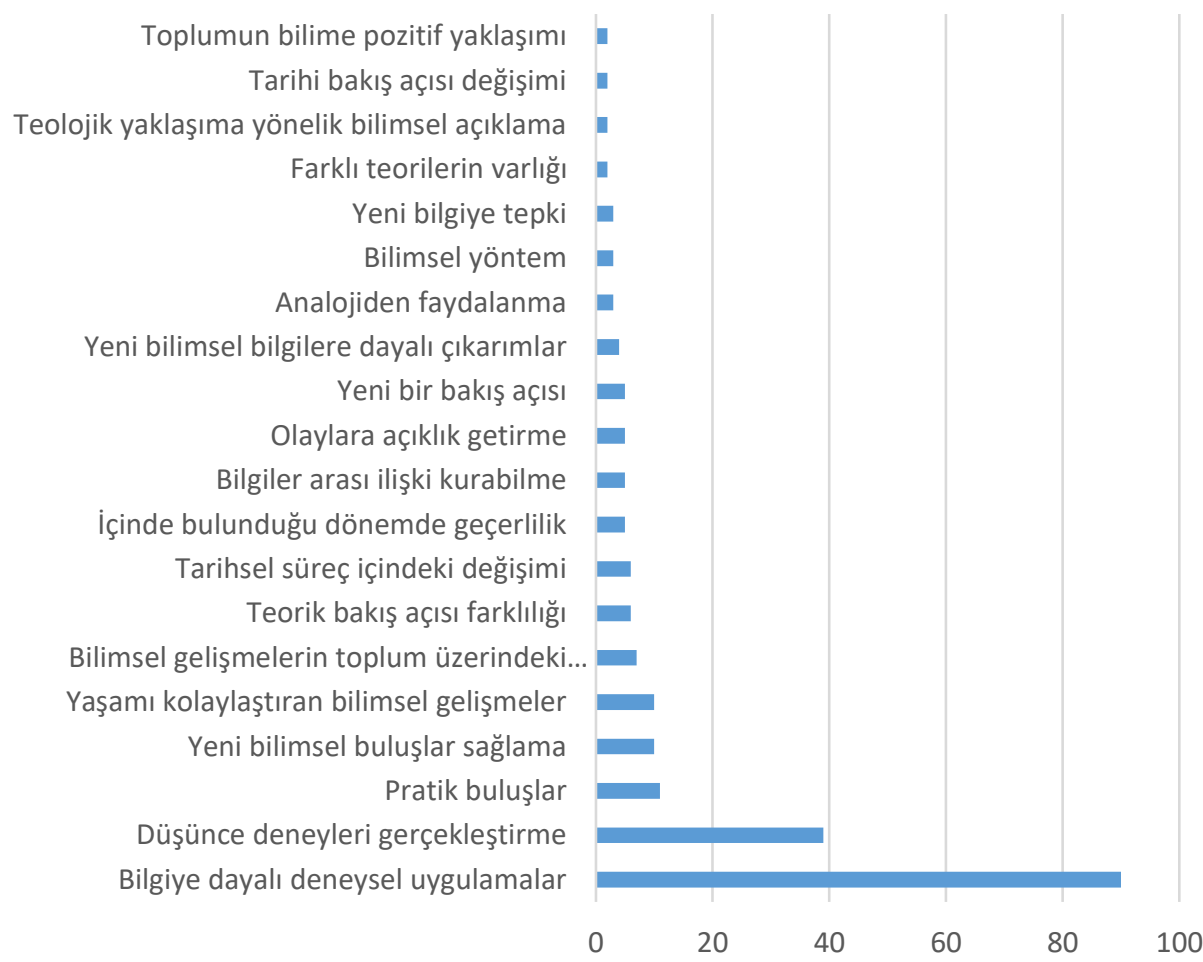

Şekil 2. Olağanüstü buluşlar isimli kitaba ilişkin kodlar 
Kitapta yer alan kodlar ve frekans değerlerine ilişkin bulgular ise Tablo 3'te verilmiştir.

Tablo 3.

Olağanüstü Buluşlar İsimli Kitapta Yer Alan Kodlar ve Frekanslarn

\begin{tabular}{ll}
\hline Kod İsmi & Frekans \\
\hline Bilgiye dayalı deneysel uygulamalar & 90 \\
Düsünce deneyleri gerçekleştirme & 39 \\
Pratik buluşlar & 11 \\
Yeni bilimsel buluşlar sağlama & 10 \\
Yaşamı kolaylaştıran bilimsel gelişmeler & 10 \\
Bilimsel gelişmelerin toplum üzerindeki etkisi & 7 \\
Teorik bakış açısı farklılı̆̆ı & 6 \\
Tarihsel süreç içindeki değişimi & 6 \\
İçinde bulunduğu dönemde geçerlilik & 5 \\
Bilgiler arası ilişki kurabilme & 5 \\
Olaylara açıklı getirme & 5 \\
Yeni bir bakış açıs & 5 \\
Yeni bilimsel bilgilere dayalı çıkarımlar & 4 \\
Analojiden faydalanma & 3 \\
Bilimsel yöntem & 3 \\
Yeni bilgiye tepki & 3 \\
Farklı teorilerin varlığı & 2 \\
Teolojik yaklaşıma yönelik bilimsel açıklama & 2 \\
Tarihi bakış açısı değişimi & 2 \\
Toplumun bilime pozitif yaklaşımı & 2 \\
& \\
Toplam Kod Sayısı & 220 \\
\hline
\end{tabular}

Tablo 3 ve Şekil 2'de yer alan ve sıklıkla karşılaşılan kodlara ilişkin ilgili kitaptan örnek kod aşağıda verilmiştir.

Kod İsmi: Bilgiye Dayalı Deneysel Uygulamalar

Sayfa: 5: “...Elektrik pili 1800 yılında İtalyan bilim adam Alessandro Volta (1745- 1827) tarafindan, yine bir İtalyan olan Luigi Galvani'nin (1737-1798) daha önceki bir keşfine dayanarak icat edildi. Galvani firtınalı ve şimşekli havalarda bir kurbağanın bacaklarına metal neşterle dokunulduğunda, hayvanın bacak kaslarının seğirdiğini görmüştü. Sakin havalarda bile kaslara aynı anda iki farklı metal parçası (örneğin bakır ve demir) dokundurulduğunda, art arda seğirmeler meydana geldiğini de gözlemledi. Bu seğirmeler Galvani ye göre "hayvansal elektrik" denilen hayati bir güçten kaynaklanıyordu. ..."

İki kültür isimli kitaba ait bulgular. Araştırma bulgularına göre, İki Kültür isimli kitaba yönelik, belirlenen bilimin doğası unsurları açısından gerçekleştirilen içerik analizi sonucunda ortaya çıkan kodlar Şekil 3'de belirtilmiştir. 


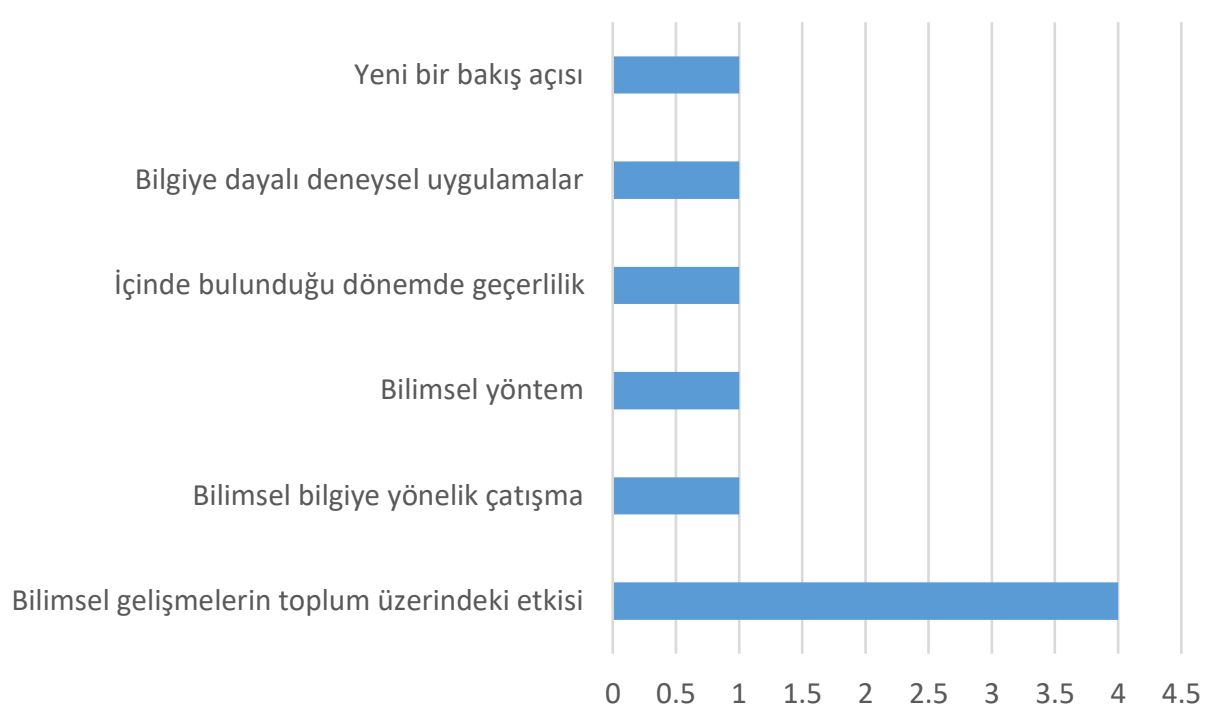

Şekil 3. İki kültür isimli kitaba ait kodlar

Kitapta yer alan kodlar ve frekans değerlerine ilişkin bulgular ise Tablo 4 'te verilmiştir.

Tablo 4.

İki Kültür İsimli Kitapta Yer Alan Kodlar ve Frekanslarn

\begin{tabular}{ll}
\hline Kod İsmi & Frekans \\
\hline Bilimsel gelişmelerin toplum üzerindeki etkisi & 4 \\
Bilimsel bilgiye yönelik çatışma & 1 \\
Nilimsel yöntem & 1 \\
İçinde bulunduğu dönemde geçerlilik & 1 \\
Bilgiye dayalı deneysel uygulamalar & 1 \\
Yeni bir bakış açısı & 1 \\
& \\
Toplam Kod Sayısı & 9 \\
\hline
\end{tabular}

Tablo 4 ve Şekil 3'de yer alan ve sıklıkla karşılaşılan kodlara ilişkin ilgili kitaptan örnek kod aşağıda verilmiştir.

Kod İsmi: Bilimsel Gelişmelerin Toplum Üzerindeki Etkisi

Sayfa: 178

"...Uygulamalı bilimin tek tek bir milyar insan hayatından gereksiz ıstırabı çıkarmayı -kendi ayrıcalıklı toplumlarımız içinde yaşarken büyük ölçüde unuttuğumuz türden bir ıstırabı, hakkında konuşmak bile kabalık sayılabilecek kadar ilkel olan ıstırabı ortadan kaldırmayımümkün kıldığını görmezden gelemeyiz. Örneğin, hastaların çoğunu nasıl iyileştireceğimizi biliyoruz. Çocukların bebekken, annelerin çocuk doğururken ölmesini önlemeyi; açlı̆̆ giderecek kadar yiyecek üretmeyi; asgari barınma koşullarını yaratmayı, çabalarımızı boşa çıkaracak kadar çok doğum olmamasını sağlamayı. Bütün bunları nasıl yapacağımızı biliyoruz...."

Meteor avı isimli kitaba ait bulgular. Her iki araştırmacı tarafından gerçekleştirilen içerik analizleri sonucunda araştırmamızda dördüncü kitap olan 
Meteor Avı isimli kitapta, bilimin doğasına yönelik belirlenen unsurlar açısından bir kod tespit edilememiştir. Bu sebeple, bu kitaba ait herhangi bir kod bulgusu bu bölümde yer almamıştır.

\section{Tartışma, Sonuç ve Öneriler}

Araştırma sonucunda elde edilen bulguları iki bölümde değerlendirelim. İlk olarak araştırmacılar tarafından gerçekleştirilen kodlama işleminin ardından Tablo 2'de yer alan kodlara yönelik kappa katsayı değerleri incelendiğinde, değerlerin genel olarak Tablo 1'de yer alan orta derece değeri etrafında toplandığ1 görülmektedir. Hatta bunların yanında Coğrafi Yapının Etkisi isimli kod ise .7746 değeri ile kappa istatistik katsayısı için büyük çapta bir uyum değerine sahiptir. Tematik gerçekleştirilen bu içerik analizi ve kodlama sürecinde bu denli bir bağımsız kodlayıcı uyumunu yakalamış olmak çalışma açısından araştırmacıları motive ettiği gibi analiz sürecini de kolaylaştırmıştır. Bu şekilde tematik analizlerde bu denli bir kod uyumunun yakalanması, ardından her iki araştırmacının bir araya gelerek görüş birliğine vardıkları süreci de oldukça kısaltmış oldu.

Kitaplara ilişkin ortaya çıkan kod değerleri incelendiğinde ise ele alınan inceleme konusu (bilimin doğası unsurları) ve kitapların işledikleri konular bazında içerikleri ile uyumlu bir sonuç ortaya çıtığı söylenebilir. Ashall (1994) tarafından ortaya konulan Olağanüstü Buluşlar isimli kitap 220 tematik kod ile incelenen dört kitap arasından en fazla tematik koda sahip olan kitap olmuştur. Olağanüstü buluşlar isimli kitapta Bilimsel Bilginin Deneysel Yapısı teması altında yer alan Bilgiye dayalı deneysel uygulamalar isimli kod sayısı 90'dır. Kitabın önsözünde Ashall özellikle iki şey üzerine vurgu yapmaktadır. Bunlardan birincisi topluma, gerçekleştirilen bilimsel çalışmaların aktarılmasının ne kadar önemli olduğu ve diğeri ise kuramsal çalışmaların desteklenerek uygulamalarının ortaya konulmasıdır. Bu tema kapsamında 18 bölüme ayrılan eserinde yazar kuramsal olarak ortaya konulan düşüncelerin, fikirlerin nasıl ürünler haline geldiğini ve yaşamlarımızı etkilediğini açıklamıştır. Dolayısı ile kitabın büyük bölümü, gerçekleştirilen deneysel çalışmalara ait olduğundan, bu konuya ilişkin 90 adet tematik kod bulunması olağandır. Kitap bu açıdan bilimsel bilginin deneysel yapısına yönelik oldukça zengin bir içeriğe sahiptir. Kitap, bilimsel bilginin deneysel yapısına yönelik Tablo 2'de belirtilen kodlardan dördünü önemli miktarda (108 Kod, toplam kodların \%49,1'i) içermektedir. Kitabın bilimin doğasına yönelik zengin bir içerik sunduğu bilimsel bilginin deneysel yapısına yönelik okuyucular elektrik ve manyetizma arasındaki ilişkiye yönelik çalışmalar, radyo dalgalarının keşfi ve kullanımı, Röntgen 'in görüntüleme üzerine gerçekleştirdiği çalışmalar ve Hubble'ın uzay çalışmaları gibi konular hakkında açıklamalara ve örneklere rahatlıkla ulaşabileceklerdir.

Yine kitapta bilimsel bilgide yaratıcılık başlığ1 altında yer alan kodlara kayda değer bir sayıda (55 adet kod ve toplam kodların \% 25'i) ulaşılmıştır. Burada okuyucular Gilbert'in Dünya' nın manyetik kutuplarına ilişkin yorumlarını, Maxwell'in elektrik ve manyetizma arasında kurmaya çalıştığı bağı ve Marie Curie'nin radyoaktivite hakkındaki yaratıcı düşüncelerine ulaşmaları mümkündür. Olağanüstü Buluşlar isimli eserin ismi bizlere hem deneysel çalışmalar hem de yaratıcılık hakkında ipuçları vermektedir. Bilim insanları ve mucitlerin ortaya koydukları çalışmaların yeryüzünde kalıcı izler bırakmasındaki en büyük sebeplerden birisi de probleme yönelik yaratıcı bir bakış açısına sahip olmalarıdır diyebiliriz. Kitap, bu örnekleri okuyucuya zengin 
bir şekilde sunuyor diyebiliriz. Kitap aynı zamanda, bilimsel bilginin değişebilirliği ve bilimsel bilginin sosyal ve kültürel yapı ile olan ilişkisine dair de örnekler sunmaktadır. DNA izlerinin adli tıpta kullanımı ve bunun toplumda uyandırdığ pozitif bakış açısına yönelik örneği, radyonun iletişimin vazgeçilmez bir parçası olması ve oksijene ait farklı kullanım alanlarının ortaya çıkması gibi toplumu etkileyen gelişmelere yönelik örnekler de kitapta mevcuttur.

Bir diğer incelediğimiz kitap, Sagan (1997) tarafından ortaya konulan Milyarlarca ve Milyarlarca isimli kitabımızdı. Bu kitapta da belirlenen bilimin doğası unsurlarına yönelik toplamda 52 tematik koda ulaşıldı. Bu kitapta da bilimsel bilginin deneysel yapısı ve bilimsel bilgide yaratıcılık unsurlarına dair kodların ağır bastığı tespit edilmiştir. Toplam 52 koddan 13'ü bilimsel bilgide yaratıcılık başlı̆̆1 altında yer alan düşünce deneyleri gerçekleştirme kodundan oluşmaktadır. Kitapta özellikle bilimsel bilgide yaratıcılık unsuru başlığı altında insan nüfusuna yönelik öngörüler, Leo Szilard tarafından gerçekleştirilen atom bombası çalışmaları ve Güneş Sistemi'nde yer alan gökcisimlerine yönelik varsayımlara ulaşmak mümkündür. Aynı zamanda yine kitapta bilimsel bilginin deneysel yapısı unsuru altında ses dalgaları, astronomi ve biyolojide yer alan konulara yönelik deneysel uygulama örnekleri de mevcuttur. Sagan tarafından ortaya konulan bu eser çalışmamız kapsamında belirlenen unsurlar açısından Olağanüstü Buluşlar kitabına nazaran daha zayıf bir portre çizmiştir. Ancak yine bizler araştırmacılar olarak bu kitabın bilimin doğası eğitiminde faydalı bir araç olarak kullanılabileceğini düşünmekteyiz.

Araştırmada yer alan diğer iki kitaba dair yorum yapmamız gerekirse Snow (1993) tarafından ortaya konulan İki Kültür isimli kitap, bilimin doğası unsurları açısından diğer iki kitaba göre oldukça zayıf bir tablo ortaya koyar iken Verne (1986) tarafından ortaya konulan Meteor Avı isimli kitapta bilimin doğası unsurlarına yönelik herhangi bir koda rastlanılmamıştır. İki Kültür isimli kitapta özellikle ortaya çıkan dokuz koddan dördünü oluşturan ve bilimsel bilginin sosyal ve kültürel yapı ile ilişkisi teması altında yer alan bilimsel gelişmelerin toplum üzerindeki etkisi isimli koda dair dört adet örnek saptanmıştır. Bu örnekler ise özellikle bilimsel gelişmelerin toplum refahı üzerindeki olumlu etkilerini açıklamaya yoğunlaşmıştır. Kitap bilimsel bilginin sosyal ve kültürel yapı ile olan ilişkisi açısından bizlere içerik sunsa da bizler bu araştırmada İki Kültür isimli kitabı bilimin doğasına yönelik belirlediğimiz unsurlar açsından diğer iki kitap olan Olağanüstü Buluşlar ve Milyarlarca ve Milyarlarca'ya nazaran yetersiz bulduk.

Araştırmada bilimin doğasına yönelik belirlediğimiz unsurlar açısından mutlak bir yeterlilik değeri bulunmamakla birlikte araştırmacılar kitapları birbirleri ve içerikleri açısından değerlendirmiştir. Tabii ki bir eğitimci ilgili dersi esnasında belirtilen üç kitaptan (Meteor Avı hariç) yararlanabilir ancak burada dört kitap arasında özellikle Olağanüstü Buluşlar'ın, bilimin doğasına yönelik eğitimde etkili bir yardımcı enstrüman olarak kullanılabileceği düşünülmektedir.

$\mathrm{Bu}$ araştırmada bu dört önemli eser araştırmacılar tarafından belirlenen bilimin doğası unsurlarına göre incelenmiştir. Gerçekleştirilen inceleme sonucunda ise ortaya çıkan kodlara ilişkin yorumlar gerçekleştirilmiştir. Genel itibari ile dört kitabı birbirleri arasında karşılaştırarak incelediğimizde Ashall (1994) tarafından ortaya konulan Olağanüstü Buluşlar isimli eserin bilimin doğasına yönelik eğitim sürecinde daha etkili bir yardımcı araç olacağı düşünülmektedir. Gerek bilim tarihine yönelik zengin içeriği ve gerek ise belirlediğimiz unsurlar açısından zengin bir içerik sunması bu kitabı etkili 
bir öğretim aracı haline getirmektedir. Popüler bilim kitaplarının eğitim sürecine entegrasyonunun önemli olduğu düşünülmektedir. Daha önce de belirtildiği gibi bu kitapların akademik kitaplara nazaran daha kolay ulaşılabilir olmaları ve kullandıkları dil açısından toplumun geniş bir kesimine hitap etmeleri sebebi ile eğitim sürecine entegrasyonları, öğrencilerin bilime karşı bakış açılarında pozitif etkiler yaratabilir. Ancak burada unutulmaması gereken husus, bu kitaplarının içerik olarak hem alan bilgisi açısından doğruluğunun hem de pedagojik olarak uygunluğunun uzman bilim insanları tarafından ortaya konulmuş olması çok önemlidir. Araştırmaya konu olan dört kitap da alanlarındaki uzmanlıklarını kanıtlamış ve otoritelerce kabul görmüş bilim insanları tarafından ortaya konulmuş olup, ülkemizin saygın bir kurumu olan Türkiye Bilimsel ve Teknolojik Araştırma Kurumu (TÜBİTAK) tarafından çeviri işlemleri ve yayınlanması gerçekleştirilen eserlerdir. Bu kitapların TÜBİTAK tarafından yayınlanıyor olması, araştırma için tercih edilmelerinde önem arz etmiştir, belirleyici bir kıstas olmuştur.

Popüler bilim kaynakları içerikleri ve tarzları itibarı ile oldukça geniş bir çerçeveye sahip olabilmektedir. İçerikleri öğretim programlarının dişına çıkabilir, ders kazanımlarının fazlasıyla dışına taşmış olabilir ancak gerçekleştirilecek bu içerik analizleri ile bu kitapların eğitime kazandırılacak ve bir öğretim aracı olarak kullanılabilecek yönleri keşfedilebilir. Sağlayacakları farklı bakış açıları ile ders ortamlarının zenginleşmesini sağlayabilir ve dersleri daha ilgi çekici bir hale getirebilir. $\mathrm{Bu}$ anlamda popüler bilim kitaplarının amaca uygun gerçekleştirilen analizleri ile eğitimcilerin ciddi birer öğretim yardımcısı olacağı düşünülmektedir. Bu araştırmada bu dört önemli kitabı bilimin doğasına yönelik belirlediğimiz unsurlar çerçevesinde incelenmiş ve yorumlanmıştır. Örneğin, Meteor Avı isimli kitapta bilimin doğasına yönelik unsura ulaşılamamış olunması, bu kitabın farklı alanlarda ya da bağlamlarda faydasız ya da yararsız olduğu anlamına gelmemektedir. Popüler bilim yayınlarına yönelik gerçekleştirilecek içerik analizleri daha nice tespit edilememiş öğretimi destekleyici içeriklerin ortaya çıkmasını sağlayabilir. Lin, Wu, Cho ve Chen'in de (2015) belirttiği gibi popüler bilim yayınlarının geniş tanıtım ağından faydalanmak, öğrencilerin derse olan ilgilerini çekmemize de oldukça yardımcı olacaktır.

Popüler bilim eğitimi, bilginin yayılımında ve bilimsel okuryazarlığın gelişmesinde etken bir role sahip olduğu gibi (Lin ve diğ., 2015) aynı zamanda informal bir şekilde toplum ya da öğrenciler için sınıf dişı öğrenme imkânı sağlamaktadır (Parkinson ve Adendorff, 2004). Bu araştırma ile aslında bir yerde de literatürde yer alan çalışmalara ek olarak informal bir öğrenme aracı olan popüler bilim kitaplarının sınıflarda nasıl yer alabileceği konusunda da görüşlere yer verilmiştir. $\mathrm{Bu}$ araştırmaya popüler bilim yayınlarının eğitimcilere öğretme ortamlarında destek olabilecek birer öğretim aracı olabileceği iddiası ile yola çıkılmıştır. Gerçekleştirilen analizler sonucu ortaya çıkan bulgular ise bu bakış açısını destekleyici nitelikte olmuştur. Öneri olarak ilerde bu alanda araştırma yapacak olan araştırmacılara, daha farklı kitapları farklı içerikler bağlamında incelemeleri ve eğitimöğretim sürecine kazandırmalarını sağlamak sunulabilir. Bu araştırma kapsamında koda ulaşılamayan Meteor Avı kitabı, farklı bir araştırma bağlamında zengin içerikler sunabilir. 


\section{Kaynakça}

Abd-El-Khalick, F., Bell, R. L. ve Lederman, N. G. (1998). The nature of science and instructional practice: Making the unnatural natural. Science Education, 82, 417437. https:/ / doi.org/10.1002/(SICI)1098-237X(199807)82:4<417::AIDSCE1>3.0.CO;2-E

Afonso, A. S. ve Gilbert, J. K. (2013). The role of “popular" books in informal chemical education. International Journal of Science Education, 3(1), 77-99. https:/ / doi.org/10.1080/21548455.2012.733439

A ğca, E. (2016). Ortaokul fen bilimleri dersi konularının öğretiminde TÜBİTAK popüler bilim kitaplarn kullanılmasının akademik başarıya etkisi (Yüksek lisans tezi). Erciyes Üniversitesi Eğitim Bilimleri Enstitüsü, İlköğretim Anabilim Dalı, Kayseri.

Akben, F. (1992). Türk basınında popüler bilim yayıncılı̆̆ı ve Bilim ve Teknik Dergisi örnek olayı. (Yüksek lisans tezi). Gazi Üniversitesi Sosyal Bilimler Enstitüsü, Ankara.

Ashall, F. (1994). Olă̆anüstü Buluşlar (G. Selamoğlu çev.) Ankara: TÜBİTAK.

Çakmakci, G. (2017). Using video vignettes of historical episodes for promoting preservice teachers' ideas about the nature of science. Science Education International, (28), 1, 7-29.

Çakmakçı, G. ve Yalaki, Y. (2012). Promoting Student Teachers' Ideas About Nature Of Science Through Popular Media. Trondheim, Norway: STEAM/NTNU.

Ekiz, D. (2009). Bilimsel araştırma yöntemleri. Ankara: Anı Yayıncılık.

Forster, N. (1995). The analysis of company documentation. C. Cassell ve G. Symon Eds.), Qualitative methods in organizational research: A practical guide. London: Sage.

Guerra, C. L. ve Payne, D. B. (1981). Using popular books and magazines to interest students in general Science, Journal of Reading, (24), 7, 583-586.

Halkia, K. ve Botouropoulou, I. (2005). Cultural and educational dimensions reflected in books popularizing scientific knowledge a case study: The Sky, a 19thcentury book popularizing astronomy, Science and Education, 14, 631-647. https:/ / doi.org/10.1007/s11191-004-5610-0

Holbrook, J. ve Rannikmae, M. (2007). The nature of science education for enhancing scientific literacy. International Journal of Science Education, 29 (3), 1347-1362. https:/ / doi.org/10.1080/09500690601007549

Kılıç, O. (2009). Çeviri yoluyla popüler bilim: Tübitak yayınları örneğinde Türkiye'de popüler bilim alanında çeviri yaklaşımları ve sorunları. (Yüksek lisans tezi). İstanbul Üniversitesi Sosyal Bilimler Enstitüsü Çeviribilim Anabilim Dalı Çeviri Bilim Dalı, İstanbul.

Landis, J. R. ve Koch, G. G. (1977). The measurement of observer agreement for categorical data. Biometrics, 33, 159-174. https:/ / doi.org/10.2307/2529310

Lederman, N. G. (1992). Students' and teachers conceptions of the nature of science: A review of the research. Journal of Research in Science Teaching, 29, 331-359. https:/ / doi.org/10.1002/tea.3660290404

Lederman, N. G. (2007). Nature of science: Past, present, and future. s. In K. Abell and N. G. Lederman (Eds.), Handbook of research on science education s. 831- 880. Mahwah, New Jersey: Lawrence Erlbaum Associates, Publishers.

Lin, S-Y., Wu, M-T., Cho, Y-I. ve Chen, H-H. (2015). The effectiveness of a popular science promotion program on nanotechnology for elementary school students in 
I-Lan City. Research in Science and Technological Education, 33(1), 22-37. https:/ / doi.org/10.1080/02635143.2014.971733

Majetic, C. ve Pellegrino, C. (2014). When science and information literacy meet: an approach to exploring the sources of science news with non-science majors. College teaching, 62(3), 107-112. https:/ / doi.org/10.1080/87567555.2014.916650

McComas, W. F. (2002). The principal elements of the nature of science: Dispelling the myths. In W. F. McComas (Ed), The nature of science in science education. Rationales and strategies s.53-70. Dordrehct: Kluwer Academic Publishers. https:/ / doi.org/10.1007/0-306-47215-5_3

McComas, W. F., Clough, M. ve Almazroa, H. (2002). The role and character of the nature of science in science education. In W. F. McComas (Ed.), The nature of science in science education. Rationales and strategies s.3-40. Dordrecht: Kluwer Academic Publishers. https://doi.org/10.1007/0-306-47215-5

National Science Teachers Association (NSTA). (1982). Science-technology-society: Science education for the1980s. (An NSTA position statement). Washington, DC: NSTA.

Parkinson, J. ve Adendorff, R. (2004). The use of popular science articles in teaching scientific literacy. English for Specific Purposes, 23, 379-396. https:/ / doi.org/10.1016/j.esp.2003.11.005

Pelger, S. ve Nilsson, P. (2016). Popular science writing to support students' learning of science and scientific literacy. Research in Science Education, 46, 439-456. https:/ / doi.org/10.1007/s11165-015-9465-y

Price, C. A., Gean, K. ve Barnes, H. (2015). The effect of live interpretation with tether on attitudes and learning of children in the mythbusters exhibit. Journal of Museum Education, 40:2, 195-206.

https:/ / doi.org/10.1179/1059865015Z.00000000095

Sagan, C. (1997). Milyarlarca ve Milyarlarca (F. Baytok çev.) Ankara: TÜBİTAK.

Simon, U. K., Steindl, H., Larcher, N., Kulac, H. ve Hotter, A. (2016). Young science journalism: writing popular science articles may contribute to an increase of high school students' interest in the natural sciences. International Journal of Science Education, 38,(5), 814-841. https:/ / doi.org/10.1080/09500693.2016.1173260

Singh, V. (2011). Using NASA science news articles to enhance learning in the classroom. The Physics Teacher, 49, 482. https://doi.org/10.1119/1.3651728

Snow, C. P. (1993). İki Kültür (T. Birkan çev.) Ankara: TÜBİTAK.

Talim ve Terbiye Kurulu Başkanlığı [TTKB, 2018]. İlköğretim Kurumları (İlkokullar ve Ortaokullar) Fen Bilimleri Dersi (3, 4, 5, 6, 7 ve 8. Sınıflar) Öğretim Programı. Ankara: MEB.

Velentzas, A. ve Halkia, K. (2007). Thought experiments in the theory of relativity and in quantum mechanics: Their presence in textbooks and in popular science books, Science ve Education, 16, 353-370. https://doi.org/10.1007/s11191-0069030-1

Verne, J. (1986). Meteor Avı (Ö. Aydın çev.) Ankara: TÜBİTAK.

Watermeyer, R. (2013). The presentation of science in everyday life: the science Show. Cultural Studies of Science Education, 8, 737-751. https://doi.org/10.1007/s11422013-9484-9 
Whitley, R. (1985). Knowledge producers and knowledge acquire Popularisation as a relation between scientific fields and their publics", Expository Science: Forms and Functions of popularisation, (T. Shinn ve Richard Whitley Ed.). (s.3-28). New York:

Springer. https://doi.org/10.1007/978-94-009-5239-3_1

Yıldırım, A. ve Şimşek, H. (2006). Sosyal bilimlerde nitel araştırma yöntemleri (5. Baskı). Ankara: Seçkin Yayıncılık.

Yıldız, M., E. (2015). Türkiye'de popüler bilim dergilerinin eleştirel ekenomi politik çözümlemesi: Bilim ve Teknik ile Popular Science örnekleri. (Yüksek lisans tezi). Anadolu Üniversitesi, Sosyal Bilimler Enstitüsü, Basın ve Yayın AnabilimDalı, Eskişehir.

\section{Summary}

\section{Introduction}

The societies considered the periods of intense scientific developments as a Renaissance and highlighted some scientific issues. During this period, scientific subjects such as the shape of the Earth, the structure of the space, nanotechnology or global warming attracted the attention of society more than the others. These subjects, which were prominent during the period and followed with interest by society, were called popular science and started to appeal to a wide audience. This is usual. Because, as Whitley (1985) states, it is possible to talk about two different bands in the environment where science exists. One of them is the field experts of science and the other is the society who are not experts in this field. The transfer of studies to individuals who are not in the field is especially important for the formation and development of the link between science and society. If we briefly describe popular science, as described by Parkinson and Adendorff (2004), it is an important field of instruction that aims to improve the level of scientific knowledge and literacy of individuals and may extend beyond the academia. Popular science publications may contain different topics. Commonly we can list these topics as follows:

- The biographies of scientists,

- The emergence of scientific developments and interesting events of the period,

- The place and effects of scientific developments in our daily lives,

- News from nowadays science and technological developments,

- Entertaining experimental applications.

When "The Special Purposes of the Curriculum" appeared in The Science Course Curriculum 2018 presented by Board of Education (Talim ve Terbiye Kurulu Başkanlığı, [TTKB]) is examined it can be found that there are serious overlaps and perspectives on the issues that are based on popular science publications. For example;

- To realize the interaction between individual, environment, and society; to raise awareness of sustainable development in society, economy and natural resources.

- Developing career awareness and entrepreneurship skills related to science.

- Helping to understand how the scientific knowledge is produced by scientists, the process of this scientific knowledge, and how it can be used in other new research areas, 
- Develop attitudes and arouse interest and curiosity about the events taking place in nature and its vicinity. (TTKB, 2018, p.9).

The aforementioned statements are also among the topics that popular science publications address. For this reason, popular science publications which are thought to have the potential to be a bridge between the nature of science, science education and the field of popular science have been included in this research. The main purpose of this research is whether popular science publications can be used as an effective tool in science teaching in terms of the nature of science.

When the literature studies about "popular science" are examined, it is possible to say that it has a wide spectrum of study groups. It is possible to come across studies carried out with both individuals in society and students in formal education. If the results obtained are evaluated in a general framework, it is possible to say that initiatives put forward in the name of popularizing science have positive effects on individuals' understanding of the scientific subject on their point of view. The wordings in popular science books (Pelger and Nilson, 2016), motivations on the students (Guerra and Payne, 1981), epistemology and communication with society (Halkia and Botouropoulou, 2005), modern physics subjects (Velentzas and Halkia, 2007), about raising the interest to the natural science (Simon, Steindl, Larcher, Kulac, and Hotter, 2016) in a word it is possible to encounter the studies in a wide range spectrum.

\section{Method}

As a research method, it was benefited from document analysis in this research. The documents included in the research are the following books which can be accessed during the research by adapting them to Turkish by The Scientific and Technological Research Council of Turkey (TÜBİTAK);

- The Chase of the Golden Meteor by Jules Verne (1986)

- The Two Cultures by Charles Percy Snow (1993)

- Remarkable Discoveries! By Frank Ashall (1994)

- Billions and Billions by Carl Sagan (1997)

The following steps were followed in document analysis Forster (1995) (as cited in Y1ldırım ve Şimşek, 2013, p. 223).

1- Reaching the documents

2- Checking the originality

3- Understanding the documents

4- Analyzing the data

4.1. Sampling the data subject to analysis

4.2. Developing the categories

4.3. Determination of the analysis unit.

4.4. Quantification

5- Using the data

A detailed data analysis is required as only four books of which names are given are used as data sources. At this stage, content analysis was made for the data. All of the four books were included in the process of content analysis. In other words, the data universe and sample included in this research are the same and the names of four books are above-stated. 
During the research, while both generating the categories and the coding process, by both of the researchers, theoretical sensitivity was taken into consideration. Theoretical sensitivity is defined as the ability of the researcher to identify the most important aspects in the data, to recognize and make sense of it in qualitative research (Ekiz, 2009, p.78). The theories put forward in the "nature of science" and "science education" guided the researchers in the data analysis process during the research. For this reason, four basic nature of science aspects stated by McComas (2002) constitute the categories in the content analysis process of the textbooks took part in the research. These are;

- Experimental nature of the scientific knowledge

- Cultural and social embeddedness in scientific knowledge

- Tentativeness in scientific knowledge

- Creativity in scientific knowledge.

\section{Results}

According to the findings of the research, the most common codes (top three) that are generated as a result of the content analysis performed for the books by the determined aspects of the nature of science are given in Table 1.

Table 1.

The Book Names and the Frequencies of the Codes

\begin{tabular}{ll}
\hline The book named Billions and Billions & \\
\hline Code & Frequency \\
Performing thought experiments & 13 \\
Knowledge-based experimental applications & 10 \\
Providing new scientific discoveries & 9 \\
The book named Remarkable Discoveries! & \\
\hline Code & Frequency \\
Knowledge-based experimental applications & 90 \\
Performing thought experiments & 39 \\
Practical inventions & 11 \\
The book named The Two Cultures & \\
\hline The impact of scientific developments on society & 4 \\
Conflict towards scientific knowledge & 1 \\
Scientific method & 1 \\
\hline
\end{tabular}

Here are some samples for the codes in the books that are abovementioned; The book named Remarkable Discoveries!

Code: Knowledge-based experimental applications

p.6

"... not long ago Faraday built his first electrical engine in 1819, Hans Christian Oersted the Danish scientist had discovered that: When a piece of wire connected to the battery with one end suspended horizontally on the compass needle, the pointer moves every time the wire is supplied. This important phenomenon called "Electromagnetic Induction" clearly proved that electricity and magnetism related to each other."

The book named The Two Cultures

Code: The impact of scientific developments on society

p.10 
"... "Science" says Huxley, "creates a part of the society and either provide a tough mental education or contributes for the welfare of the nation".

\section{Discussion and Pedagogical Implications}

When the book named Remarkable Discoveries! is evaluated in general terms, it is thought that it can be used as an auxiliary resource -especially in terms of examplesin the courses including the history of science and the structure of scientific knowledge in formal education. As a result of the examinations of the book, it is thought that the students' interest in the course and awareness of the history of science can be raised with the examples that can be given under the title of history of science.

According to findings of the study, the book named Billions and Billions put forward by Sagan (1997) draws a weaker portrait than the book named Remarkable Discoveries! in terms of determined nature of science aspects. However, it has been still thought that "Billions and Billions" can be still used as an effective tool for teaching the nature of science.

Popular science resources can have a very broad framework in terms of their content and style. Their contents may go out of the curriculum, may have overstated the learning outcomes, but with these contents analyses, aspects of these books that can be used for teaching and used as a teaching tool can be discovered. They can enrich the course environments with different perspectives and make the lessons more interesting. In this sense, it is thought that popular science bo7oks can be a serious assistant for educators during the learning process with expedient analysis

\section{Araştırmanın Etik Taahhüt Metni}

Yapılan bu çalışmada bilimsel, etik ve alıntı kurallarına uyulduğu; toplanan veriler üzerinde herhangi bir tahrifatın yapılmadığı, karşılaşılacak tüm etik ihlallerde "Cumhuriyet Uluslararası Eğitim Dergisi ve Editörünün" hiçbir sorumluluğunun olmadığı, tüm sorumluluğun Sorumlu Yazara ait olduğu ve bu çalışmanın herhangi başka bir akademik yayın ortamına değerlendirme için gönderilmemiş olduğu sorumlu yazar tarafından taahhüt edilmiştir.

\section{Authors' Biodata/ Yazar Bilgileri}

Barış EROĞLU Aksaray Üniversitesi Eğitim Fakültesi Temel Eğitim Bölümü'nde Dr. Öğretim Üyesi olarak görev yapmaktadır.

Barış Eroğlu works at Aksaray University, Faculty of Education, Department of Primary Education as an Assistant Professor.

Halil İbrahim SAĞLAM Aksaray Üniversitesi Rektörlük İdari Birimlerinde görev yapmaktadır. Sınıf Öğretmenliği Yüksek Lisans mezunudur.

Halil İbrahim Sağlam works at Administrative Units of the Rectorate of Aksaray University as an administrative staff. He has a master's degree in classroom education. 